\title{
Enterococcus casseliflavus
}

National Cancer Institute

\section{Source}

National Cancer Institute. Enterococcus casseliflavus. NCI Thesaurus. Code C86365.

A species of facultatively anaerobic, Gram-positive, cocci shaped bacteria in the phylum Firmicutes. This species is motile, non-spore forming, catalase negative, esculin positive, hippurate positive, does not produce hydrogen sulfide, does not reduce nitrate and does not hydrolyze casein, gelatin or urea. E. casseliflavus has been isolated from plants, silage, soil and is commensal in the human Gl tract, but has been associated with various human infections and has low level vancomycin resistance. 